\title{
Types of urinary stones in Duhok Province
}

\author{
Khalis Sabri Ammo \\ *Department of Surgery, School of Medicine, Faculty of Medical Sciences, University of Duhok.
}

(Ann. Coll. Med. Mosul 2012; 38 (2): 40-43).

Received: $1^{\text {st }}$ Feb. 2012; Accepted: $9^{\text {th }}$ Jul. 2012.

\section{ABSTRACT}

Aim: This study was conducted to evaluate the biochemical composition of urinary stones in Dohuk Province.

Patients and methods: A prospective study done at Azadi-Teaching Hospital in Duhok city, during a period of two years from Jun. 2009 to Jun. 2001. The total number of patients collected was 150. Both inpatients and outpatients were included. Pediatric age group excluded.

The source of collection of samples was: stones passed spontaneously by the patient with conservative treatment, or after surgery or extra corporeal shock wave lithotripsy (ESWL).

Results: Total number of patients was 150, 102 patients (68\%) were males \& 48 patients (32\%) were females, male: female ratio $=2.1: 1$. Out of 150 patients, $52(35 \%)$ had calcium phosphate, $45(30 \%)$ had calcium oxalate, and $30(20 \%)$ with uric acid stones. 20 patients (13\%) had mixed stones "calcium phosphate and calcium oxalate" and only 3 patient (2\%) had pure oxalate stones.

Out of 150 patients, $117(78 \%)$ had calcium stones \& 30 patients (20\%) had uric acid stones, \& 3 patients (2\%) had oxalate stone. No other types of stones were detected in this study.

Conclusion: The study revealed that most of the stones in our patients were calcium containing stones. The most common stones were calcium phosphate, and the percentage of uric acid stones was high.

الخلاصة

الهدف من البحث: در اسة التكوين الكيميائي لحصى المسالك البولية في مدينة دهوك.

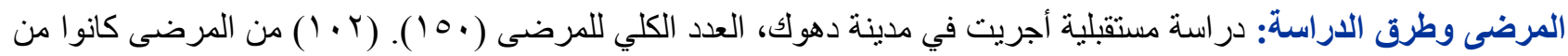

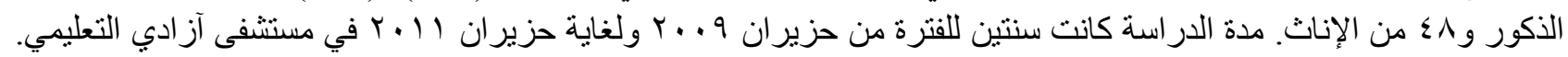
شملت الدر اسة المرضى الر اقدين و مرضى العينى ملادة الخارجية. أستبعد الأطفال من الدر اسة. استحصلت النماذج من المرضى الذين عولجوا تحفظيا وتخلصوا من الحصى عن طريق الاحليل أو المرضى الذين عولجوا بالتفتيت أو التداخل الجر احي.

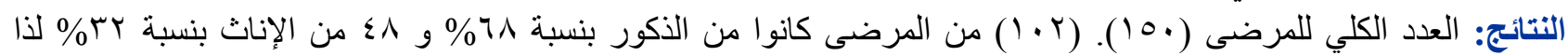

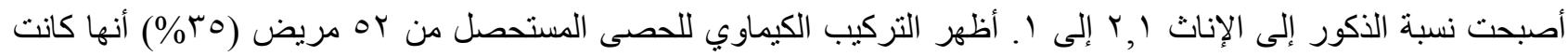

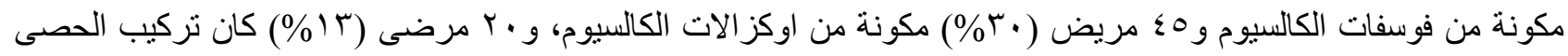

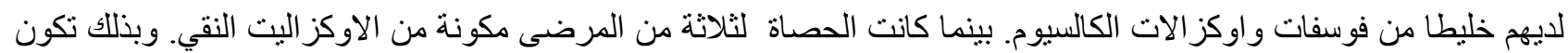

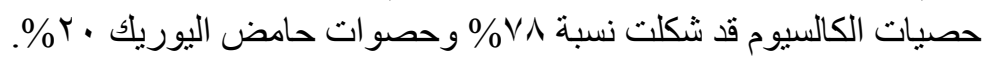
الاستتناج: أظهرت الدراسة أن غالبية حصى المجاري البولية في مدينة دهوك كانت تحوي على عنى عصر الكالسيوم. وان غالبيتها كانت مكونة من فوسفات الكالسيوم وان حصى حامض اليوريك شكلت نسبة عالية. 
U rinary calculi are worldwide in its distribution but the overall probability of forming stones varies in different parts of the world. The risk of developing nephrolithiasis in normal adults appears to be lower in Asia (1-5\%) than Europe (5$9 \%$ ) and North America (12\% in Canada, $13 \%$ in USA). The highest risk was reported in Saudi Arabia $(20.1 \%){ }^{(1)}$ Prevalence rate is $4-15 \%$ in males and $4-8 \%$ in females and the incidence rate varies from area to area: 53.2 per 100,000 population in Japan, 364 in Malaysia and 540 in Germany. Prevalence and/or incidence rates have, in general, increased in the developed countries since World War II and in the developing countries as well, where upward trends are quite analogous to the trends observed in the $19^{\text {th }}$ century in Europe. ${ }^{(2)}$ The incidence of urinary tract stones in Japan has also increased steadily over the past 30 years and seems that it will continue to do so in the near future. ${ }^{(3)}$

There are different types of calculi. Most stones $75-80 \%$ are calcium containing stones composed largely of calcium oxalate followed by calcium phosphate. Another $10-15 \%$ are struvite stones composed of magnesium ammonium phosphate. Six percent are uric acid stone and 1-2\% are made up of cystine stones. An organic matrix of mucoprotein makes up about $2.5 \%$ of all stones by weight..$^{(4)}$

The epidemiology of urolithiasis differs according to geographical area and historical period. Changing socioeconomic conditions have generated changes in the incidence and type of lithiasis in terms of both the site and the physicalchemical composition of the calculi. ${ }^{(5)}$

Renal stones formation is believed to be the result of both excessive concentration of the stone forming constituents and some physicochemical situations. Important factors are high concentration of urinary excretory products because of highly concentrated urine, resulting from environmental or habitual chronic dehydration. Hypercalciuria from various causes, excessive oxalate or uric acid production or an acquired or genetic basis and hereditary cystinuria are important causes. The factors conducive to precipitation of crystalloid may be equally important. An alkaline $\mathrm{pH}$ favors calcium phosphate stone formation. ${ }^{(6)}$

So, these metabolic derangements are found in patients with idiopathic calcium stone disease: idiopathic hypercalciuria in $49.5 \%$ of patients, hyperoxaluria in $27.8 \%$, hyperuricosuria in $23.0 \%$, hypocitraturia in 22.6 and low urine volume in $10.9 \%$. $18.8 \%$ of patient has no any identifiable metabolic changes. $^{(1)}$

Analysis of $24 \mathrm{~h}$ urine specimens from stoneforming patients reveals seasonal variations in urinary risk factors for nephrolithiasis. Urine volume, $\mathrm{pH}$ and sodium are significantly lower during the summer than in the winter. These changes are consistent with summer time, sweating and increased physical activity. The decrease in urine $\mathrm{pH}$ causes relative super saturation of uric acid, which is far more marked in men. The summer time sodium depletion is modest and urine calcium is not increased in this time, but in male patients, remarkable decrease in urine volume causes high calcium oxalate super saturation. Females have maximum calcium oxalate super saturation in early winter because of decreasing urine volume and increasing urine calcium excretion. ${ }^{(7,8)}$

\section{Aim of the study}

Since the chemical composition of urinary calculi is very important for the purpose of determining both the origin and etiology, a study was therefore, done to know the biochemical composition of urinary calculi in Duhok Province.

\section{PATIENTS AND METHODS}

Total number of patients collected was 150, 102 males \& 48 females, during the period of two years from Jun. 2009 to Jun. 2011, at Azadi-Teaching Hospital (Dohuk). Both in and outpatients were included. Pediatric age group excluded from this study.

The source of collection of samples was stones passed spontaneously by the patients after conservative treatment, or ESWL, and surgically extracted stones. These stones were washed in distilled water, grinded and powdered in a mortar and were analyzed by chemical quantitative method.

The kits supplied by Biolabo SA (France) were used for chemical analysis of stones. The synthetic control available in the form of fine power was analyzed along with the test samples. 


\section{RESULTS}

The total number of patients was 150. 102 patients (68\%) were males \& 48 (32\%) were female. The Male: Female ratio was 2.1:1. Out of 150 patients, 52 (35\%) had calcium phosphate stones, 45 (30\%) had calcium oxalate and $30(20 \%)$ had uric acid stones. Mixed stones (calcium phosphate and calcium oxalate) were found in 20 patients (13\%) \& 3 patients (2\%) had pure oxalate stone (Table 1).

Regarding the sex distribution, in the males the composition was calcium phosphate in 36 patients (35.6\%), calcium oxalate in 33 patients $(32.3 \%)$, pure uric acid stones in 20 patients (19.6\%). Mixed type (calcium phosphate and calcium oxalate) was found in 10 patients (9.8\%). 3 patients (2.9\%) had pure oxalate stone (Table 2 ).

On the other hand in females 17 patients (35.4\%) had calcium phosphate stones, 13 (27\%) had calcium oxalate, $10(20.8 \%)$ with mixed type \& 8 patients $(16.6 \%)$ had pure uric acid stone (Table 3).

Out of 150 patients, $117(78 \%)$ the stones were calcium stones \& $30(20 \%)$ had uric acid stones \& 3 patients (2\%) had oxalate stone. No other types of stones were detected in this study like cystine or other rare types.

Table1. Chemical compositions of stones.

\begin{tabular}{|l|c|c|}
\hline \multicolumn{1}{|c|}{ Type of stones } & $\begin{array}{c}\text { No. of } \\
\text { patients }\end{array}$ & Percentage \\
\hline Calcium phosphate & 52 & $35 \%$ \\
\hline Calcium oxalate & 45 & $30 \%$ \\
\hline Uric acid stone & 30 & $20 \%$ \\
\hline $\begin{array}{l}\text { Calcium phosphate } \\
\text { \& calcium oxalate }\end{array}$ & 20 & $13 \%$ \\
\hline Oxalate stones & 3 & $2 \%$ \\
\hline Total & 150 & 100 \\
\hline
\end{tabular}

Table 2. Stone analysis in males.

\begin{tabular}{|l|c|c|}
\hline \multicolumn{1}{|c|}{ Type of the stones } & $\begin{array}{c}\text { No. of } \\
\text { patients }\end{array}$ & Percentage \\
\hline Calcium phosphate & 36 & 35.6 \\
\hline Calcium oxalate & 33 & 32.3 \\
\hline Uric acid & 20 & 19.6 \\
\hline Mixed stones & 10 & 9.7 \\
\hline Pure oxalate & 3 & 2.8 \\
\hline Total & 102 & $100 \%$ \\
\hline
\end{tabular}

Table 3. Stone analysis in females.

\begin{tabular}{|l|c|c|}
\hline \multicolumn{1}{|c|}{ Type of the stones } & $\begin{array}{c}\text { No. of } \\
\text { patients }\end{array}$ & Percentage \\
\hline Calcium phosphate & 17 & 35.5 \\
\hline Calcium oxalate & 13 & 27 \\
\hline Mixed stones & 10 & 20.8 \\
\hline Pure uric acid stones & 8 & 16.7 \\
\hline Total & 48 & 100 \\
\hline
\end{tabular}

\section{DISCUSSION}

We found that males were more prone to urinary stones than females, with a ratio of 2.1:1. Others have observed similar ratios. ${ }^{(9-12)}$ This might be related to hormonal effects, high inhibitory activity, lower food intake and lower body size. ${ }^{(11)}$ In addition, Welshman and McGeown demonstrated increased citrate concentrations in the urine of women. ${ }^{(13)}$ It has been postulated that this may aid in protecting females from calcium urolithiasis since citrate inhibits nucleation of calcium oxalate crystals. $^{(14)}$

In our study the most common type of stones were calcium stones either in the form of calcium phosphate or calcium oxalate or a mixture of both (78\%). Nearly similar results were found in other studies. $^{(9,10,15)}$

Calcium stones analysis of our patients revealed that the percentage of calcium phosphate was (35\%) which differ from other studies, which found that the main calcium stones were calcium oxalate, like the study done by Rahman et al in 2008. ${ }^{(16)}$

The causes of calcium oxalate stones are idiopathic Hypercalciuria, hypercalciuric conditions, low urinary citrate, hyperoxaluria and hyperuricosuria. ${ }^{(17)}$ Hypercalcaemic conditions causing Hypercalciuria include primary hyperparathyroidism, granulomatous disease, hyperthyroidism phaeochromocytoma, vitamin $D$ intoxication and thiazide diuretic therapy. ${ }^{(18)}$

The formation of calcium phosphate stones is associated with conditions such as hyperparathyroidism and renal tubular acidosis. ${ }^{(19)}$ We think that in our locality more investigations should be done in order to exclude such underlying conditions.

In our study the uric acid stones percentage was (20\%), which differ from other studies (5-10\%), like in study done in Baghdad in 2006 by Gaader and L.K-Mahdi ${ }^{(15)}$ and other study in Jordan in 2007 by lyad Ahmed Aboud. ${ }^{(20)}$ We think the cause behind 
that might be dietary cause (high protein diet). Proteins may contribute to stone formation by increasing the acidity of urine and increasing the urinary excretion of uric acid, phosphorous and calcium. ${ }^{(21,22)}$

\section{CONCLUSION}

Males are more prone to urolithiasis. The commonest stones were calcium containing stones in our locality, among them the commonest were calcium phosphate, and the percentage of uric acid stones was high.

\section{REFERENCES}

1. Adriano R, Vitale C, Marangella M. Epidemiology of nephrolithiasis. J. Nephro. 2000;13: 65-70.

2. Kodama $\mathrm{H}$, Ohno $\mathrm{Y}$, Kiyo $\mathrm{H}$. Descriptive Epidemiology of Urolithiasis 1989;35 (6): 923-934.

3. Yoshida O, Terai A, Ohkawa T, Okada Y. National trend of the incidence of urolithiasis in Japan from 1965-1995. Kidney Int. 1999; 56 (5).

4. Vmay K, Abul A K, Fausto N, Mitchell NR. Renal stones in: Robbins Basic pathology. $8^{\text {th }}$ ed. Saunders Company; 2007.p: 571-572,1899-1904.

5. Trinchieri A. Epidemiology of urolithiasis. Arch. Ital. Urol. Androl. 1996;68(4): 203-249.

6. Jager $P$. Genetic versus environmental factors in renal stone disease. Curr. Opinn. Nephro. Hyperten, 1996;р. 5342-5346.

7. Stuart RO, Hill K, Poindexter J, Pak CY. Seasonal variations in urinary risk factors among patients with nephrolithiasis. J. Lithotr. Stone Dis. 1991;3 (1): 1827.

8. Parks JH, Barsky R, Coe FL. Gender differences in seasonal variation of urine stone risk factors. J. Urol 2003;170 (2Pt 1): 384-388.

9. Thamer NA. Metabolic study on renal stone disease in Iraq [thesis]. Baghdad, University of Baghdad, 1988.

10. Fahad HG. A study on bacteria associated with kidney stones [thesis]. Baghdad, University of Baghdad, 2001.
11. AL-Mahdawi ZM. The relationship between renal calcification levels and drinking water [thesis]. Baghdad, University of Baghdad. 1999.

12. AL Maliki MA. Renal stones a study in medical geochemistry [thesis]. Baghdad, University of Baghdad. 1998.

13. Welshman SG, McGeown MG. The relationship of urinary cat ions, calcium magnesium, sodium and potassium, in patients with renal calculi. British journal of urology 1975;47(3):237-42.

14. Nicar MJ, hill K, Pak CY. Inhibition by citrate of spontaneous precipitation of calcium oxalate in vitro. Journal of bone and miniral research 1987;2(3):21520.

15. Gaader DS, Yousif SY, Mahdi LK. Prevalence and etiology of urinary stones in hospitalized patients in Baghdad. Eastren Mediterranean Health Journal 2006;12:853-861.

16. Rahman A, Danish KF, Zafar A A, Chaudhry AR. Chemical composition of non-infected upper urinary tract calculi. Rawal Medical J 2008;33:54-55.

17. Echoo-Kang. Chemical composition of urinary tract stones at the university hospital of the west indies. West Indian Med. J. 2008;57:135-139.

18. Langman CB. The molecular basis of kidney stones. Curr Opin Pediatr 2004;16:188-93.

19. Moe O W. Kidney Stones: pathophysiology and medical management .The Lancet 2006;367(9507): 333-344.

20. Abboud I A. Mineralogy \& Chemistry of urinary stones -Patients from north Jordan - Study in medical Geochemistr [thesis]. Al al-Bayt University Projects. 2006.

21. Roberston WG, Peacock M, Heyburn PJ. The risk of calcium stone formation in relation to affluence and daietary animal protein. In: Brockis JG, Finlyson BP, eds. Urinary calculus. Littleton: Massachusttes, PSG Publishing Company;1981.p.3-12.

22. Robertson Wg, Peacock M, Marshall $\mathrm{DH}$. The prevalence of urinary stone disease in practicing vegetarians. Fortschritte der urology and nephrology1981;17:6-14. 